\title{
Pengaruh Ukuran Perusahaan Terhadap Audit Delay (Studi Empiris Pada Perusahaan Pertambangan Yang Terdaftar Di Bursa Efek Indonesia Tahun 2015)
}

\author{
Dudi Badruzaman ${ }^{1}$, Nuraeni ${ }^{2}$ \\ ${ }^{1}$ Fakultas Hukum Ekonomi Syari'ah STAI Sabili Bandung \\ ${ }^{2}$ Fakultas Hukum Ekonomi Syari'ah STAI Sabili Bandung \\ Email : badruzaman.dudi@yahoo.com
}

direvisi: 14 Januari 2019 dipublikasikan: 31 Januari 2019

\begin{abstract}
Abstrak
Penelitian ini bertujuan untuk meneliti kembali 1) Ukuran perusahaan pada perusahaan pertambangan yang terdaftar di BEI pada tahun 2015. 2) Audit delay pada perusahaan pertambangan yang terdaftar di BEI pada tahun 2015. 3) Pengaruh ukuran perusahaan terhadap audit delay pada perusahaan pertambangan yang terdaftar di BEI pada tahun 2015. Populasi dalam penelitian ini adalah seluruh perusahaan pertambangan yang terdaftar di Bursa Efek Indonesia pada Tahun 2015 yaitu sebanyak 41 perusahaan. Teknik pengambilan sampel dalam penelitian ini menggunakan sampling purposive. Berdasarkan kriteria yang telah ditentukan, maka menghasilkan sampel sebanyak 10 perusahaan pertambangan. Metode yang digunakan dalam penelitian ini yaitu metode deskriptif dengan pendekatan kuantitatif. Sumber data dalam penelitian ini adalah data sekunder. Sedangkan untuk menganalisis data yang diperoleh digunakan Analisis Regresi Linier Sederhana, Analisis Koefisien Korelasi, Koefisien Determinasi, Uji Hipotesis (Uji Signifikansi atau Uji t) dan Uji Kecocokan Model (Uji F). Hasil dari penelitian dan pengolahan data menunjukan bahwa ukuran perusahaan berpengaruh negatif terhadap audit delay pada perusahaan pertambangan yang terdaftar di BEI Tahun 2015. Artinya semakin besar ukuran perusahaan maka audit delay akan semakin cepat. Berarti perusahaan akan tepat waktu dalam penyampaian laporan keuangannya. Dan sebaliknya semakin kecil ukuran perusahaan maka audit delay akan semakin lama.
\end{abstract}

Kata Kunci : Ukuran Perusahaan, Audit Delay, Bursa Efek Indonesia

\begin{abstract}
Abstrack
This study aims to re-examine 1) The size of the company in a mining company listed on the Indonesian Stock Exchange in 2015. 2) Audit delay on mining companies listed on the IDX in 2015. 3) The effect of company size on audit delay on mining companies registered in IDX in 2015. The population in this study were all mining companies listed on the Indonesia Stock Exchange in 2015, which were 41 companies. The sampling technique in this study used purposive sampling. Based on predetermined criteria, it produces a sample of 10 mining companies. The method used in this study is descriptive method with a quantitative approach. The data source in this study is secondary data. Whereas to analyze the data obtained used Simple Linear Regression Analysis, Correlation Coefficient Analysis, Determination Coefficient, Hypothesis Test (Significance Test or t Test) and Model Suitability Test (Test $F)$. The results of research and data processing show that the size of the company negatively affects audit delay in mining companies listed on the Indonesian Stock Exchange in 2015. This means that the larger the size of the company, the audit delay will be faster. Means the company will be on time in submitting its financial statements. And conversely the smaller the size of the company, the longer the audit delay will be.
\end{abstract}

Keywords: Company Size, Audit Delay, Bursa Efek Indonesia 


\section{Pendahuluan}

Setiap perusahaan yang telah terdaftar di Bursa Efek Indonesia (BEI) diwajibkan untuk menyampaikan laporan keuangan yang telah disusun sesuai dengan Standar Akuntansi Keuangan (SAK) dan telah diaudit oleh akuntan publik yang terdaftar di Badan Pengawas Pasar Modal (BAPEPAM). Berdasarkan Keputusan Ketua Badan Pengawas Pasar Modal (BAPEPAM) dan Lembaga Keuangan (LK) Nomor: Kep-134/BL/2006 Peraturan Nomor X.K.6 tentang kewajiban penyampaian laporan tahunan bagi emiten atau perusahaan publik yang menyebutkan laporan tahunan wajib memuat laporan keuangan tahunan yang disusun sesuai dengan Standar Akuntansi Keuangan (SAK) yang ditetapkan oleh Ikatan Akuntan Indonesia (IAI) dan peraturan Badan Pengawas Pasar Modal (BAPEPAM) dan Lembaga Keuangan (LK) di bidang akuntansi serta wajib diaudit oleh Akuntan yang terdaftar di BAPEPAM-LK .

Salah satu yang menjadi kendala bagi perusahaan dalam mempublikasikan laporan keuangan kepada masyakat dan kepada (BAPEPAM) yaitu ketepatan waktu yang dibutuhkan auditor untuk menyelesaikan laporan auditnya. Auditor memerlukan waktu yang relatif lama guna mencari bukti-bukti atas laporan keuangan yang telah dikeluarkan oleh perusahaan. Sehingga menimbulkan dilema bagi auditor berkaitan dengan profesional, yang harus menyampaikan laporan keuangan auditannya dengan tepat waktu. Hal ini menjadi trigger atau pemicu terjadinya audit delay .

Audit delay diukur berdasarkan lamanya hari yang dibutuhkan untuk memperoleh laporan keuangan auditor independen atas audit laporan keuangan perusahaan sejak tanggal tutup buku perusahaan, yaitu per 31 Desember sampai tanggal yang tertera pada laporan auditor independen. Audit delay yang melewati batas waktu ketentuan BAPEPAM-LK akan berdampak pada keterlambatan publikasi laporan keuangan dan apabila sampai batas waktu yang telah ditentukan belum juga menyampaikan laporan keuangannya, bursa akan melakukan pemberhentian saham sementara dan perusahaan akan dikenakan sanksi sesuai dengan yang telah ditetapkan . Pentingnya publikasi laporan keuangan auditan sebagai informasi yang sangat bermanfaat bagi para pelaku bisnis di pasar modal, manfaat suatu laporan keuangan akan berkurang apabila laporan tersebut tidak disajikan tepat waktu. Jarak waktu penyelesaian audit laporan keuangan yang ikut mempengaruhi manfaat informasi laporan keuangan auditan yang dipublikasikan serta faktor-faktor yang mempengaruhi audit delay menjadi objek yang signifikan untuk diteliti lebih lanjut. 
Salah satu faktor yang mempengaruhi audit delay yaitu ukuran perusahaan. ukuran perusahaan adalah besar kecilnya suatu perusahaan yang diukur dari besarnya total kekayaan yang dimiliki oleh suatu perusahaan. Meskipun penelitian telah banyak dilakukan mengenai audit delay pada perusahaan yang terdaftar di Bursa Efek Indonesia namun hasil penelitian tersebut beragam, hal ini disebabkan karena perbedaan sifat variabel independen dan variabel dependen yang diteliti, perbedaan periode pengamatan serta perbedaan dalam metodologi statistik yang digunakan.

Penelitian ini bertujuan untuk mengetahui ukuran perusahaan pada perusahaan pertambangan yang terdaftar di BEI pada tahun 2015, mengetahui audit delay pada perusahaan pertambangan yang terdaftar di BEI pada tahun 2015 dan mengetahui pengaruh ukuran perusahaan terhadap audit delay pada perusahaan pertambangan yang terdaftar di BEI pada tahun 2015.

\section{Metode Penelitian}

Metode yang digunakan dalam penelitian ini adalah metode penelitian deskriptif dengan pendekatan kuantitatif.

\section{Teknik Analisis Data}

\section{Analisis Regresi Linear Sederhana}

Analisis regresi sederhana dapat dimanfaatkan untuk mengetahui bagaimana variabel dependen (kriteria dapat diprediksikan melalui variabel independen/predikator. Adapun persamaan regresi linear sederahana adalah berikut :

$$
\mathrm{Y}=\mathrm{a}+\mathrm{bx}
$$

Di mana :

$$
\begin{aligned}
\mathrm{Y} & =\text { Variabel dependen (nilai yang diprediksikan) } \\
\mathrm{X} & =\text { Variabel Independen } \\
\mathrm{a} & =\text { Konstanta (nilai } \mathrm{Y} \text { apabila } \mathrm{X}=0 \text { ) } \\
\mathrm{b} & =\text { Koefisien regresi (nilai peningkatan atau penurunan). }
\end{aligned}
$$

Untuk mencari nilai a dapat menggunakan rumus:

$$
\mathrm{a}=\frac{(\Sigma \mathrm{Y})\left(\Sigma \mathrm{X}^{2}\right)-(\Sigma \mathrm{X})(\Sigma \mathrm{XY})}{\mathrm{n}\left(\Sigma \mathrm{X}^{2}\right)-(\Sigma \mathrm{X})^{2}}
$$


Sedangkan untuk mencari nilai $b$ dapat menggunakan rumus :

$$
\mathrm{b}=\frac{\mathrm{n}\left(\sum \mathrm{XY}\right)-\left(\sum \mathrm{X}\right)\left(\sum \mathrm{Y}\right)}{\mathrm{n}\left(\sum \mathrm{X}^{2}\right)-\left(\sum \mathrm{X}\right)^{2}}
$$

\section{Analisis Koefisien korelasi}

Koefisien korelasi sederhana menunjukan seberapa besar hubungan yang terjadi antara dua variabel. Untuk menghitung Analisis Koefisien Korelasi, maka dalam penelitian ini akan digunakan rumus Koefisien Korelasi Product Moment sebagai berikut :

$$
\frac{\mathrm{n}\left(\sum \mathrm{XY}\right)-\left(\sum \mathrm{X}\right)\left(\sum \mathrm{Y}\right)}{\sqrt{\left\{\mathrm{n}\left(\mathrm{X}^{2}\right)-(\mathrm{X})^{2}\right\}\left\{\mathrm{n}\left(\sum \mathrm{Y}^{2}\right)-\left(\sum \mathrm{Y}\right)^{2}\right.}}
$$

Keterangan :

$$
\begin{aligned}
r_{x y} & =\text { Koefisien Korelasi Product Moment antara X dan Y } \\
\mathrm{X} & =\text { Variabel Independen } \\
\mathrm{Y} & =\text { Variabel Dependen } \\
\mathrm{n} & =\text { Jumlah Responden }
\end{aligned}
$$

Untuk mengetahui tingkat hubungan koefisien korelasi dapat digunakan tabel sebagai berikut:

Tabel 1

Pedoman Untuk Memberikan Interprestasi Koefisien Korelasi

\begin{tabular}{cc}
\hline Interval Koefisien & Tingkat Hubungan \\
\hline $0,000-0,199$ & Sangat Lemah \\
\hline $0,200-0,399$ & Lemah \\
\hline $0,400-0,599$ & Sedang \\
\hline $0,600-0,799$ & Kuat \\
\hline $0,800-1,000$ & Sangat Kuat \\
\hline
\end{tabular}

Sumber : (Sugiyono, 2015:287)

\section{Koefisien Determinasi (KD)}

Analisis korelasi dapat dilanjutkan dengan menghitung koefisien determinasi, dengan cara mengkuadratkan koefisien yang ditemuka. Adapun rumus koefisien determinasi adalah sebagai berikut: 


$$
\mathrm{KD}=(\mathrm{r})^{2} \times 100 \%
$$

Keterangan :

$$
\begin{array}{ll}
\mathrm{KD} & =\text { Nilai Koefisien determinasi } \\
\mathrm{r} & =\text { Nilai koefisien korelasi product moment }
\end{array}
$$

\section{Uji Hipotesis (Uji Signifikansi atau Uji t)}

Uji signifikan atau uji $\mathrm{t}$ digunakan untuk menguji apakah suatu variabel bebas berpengaruh atau tidak terhadap variabel terikat". Adapun rumus uji signifikan atau uji t sebagai berikut :

$$
t_{\text {hitung }}=\frac{r \sqrt{n-2}}{\sqrt{1-r^{2}}}
$$

Keterangan :

$$
\begin{aligned}
& \mathrm{t}=\text { nilai } \mathrm{t} \text { hitung } \\
& \mathrm{r}=\text { nilai koefisien korelasi } \\
& \mathrm{n}=\text { lama tahun }
\end{aligned}
$$

Dasar pengambilan keputusan; Jika $t_{\text {hitung }}>t_{\text {tabel }}$ maka hipotesis diterima, artinya terdapat pengaruh positif antara variabel ukuran perusahaan terhadap audit delay. Jika $t_{\text {hitung }}<t_{\text {tabel }}$ maka hipotesis ditolak, artinya tidak terdapat pengaruh positif antara ukuran perusahaan terhadap audit delay.

\section{Hasil Dan Pembahasan}

\section{Ukuran Perusahaan pada Perusahaan Pertambangan yang Terdaftar di BEI Tahun 2015}

Ukuran perusahaan adalah besar kecilnya suatu perusahaan dengan melihat dari total asset, besarnya penjualan dan equity perusahaan. Salah satu tolak ukur yang menunjukan besar kecilnya perusahaan adalah total asset perusahaan tersebut. Adapun ukuran perusahaan pada perusahaan pertambangan pada tahun 2015 yaitu sebagai berikut: 
Sentralisasi Volume 8 (1) Hal : 43-56 | 2019

Pengaruh Ukuran Perusahaan Terhadap Audit Delay...

DOI: https://doi.org/10.33506/sl.v8i1.381

Dudi Badruzaman

Tabel 2

Ukuran Perusahaan

pada Perusahaan Pertambangan yang Terdaftar di BEI

Tahun 2015

\begin{tabular}{|c|c|c|c|c|}
\hline No & Kode & Nama Perusahaan & Total Asset & Ln Total Asset \\
\hline 1 & ANTM & Aneka Tambang Tbk & Rp 30.356.850.890.000 & 31,04 \\
\hline 2 & CITA & Cita Mineral Investindo Tbk & Rp $\quad 2.795 .962 .339 .721$ & 28,66 \\
\hline 3 & CKRA & Cakra Mineral Tbk & $\mathrm{Rp} \quad 982.635 .337 .920$ & 27,61 \\
\hline 4 & CTTH & Citatah Tbk & $\mathrm{Rp} \quad 605.667 .034 .867$ & 27,13 \\
\hline 5 & ELSA & Elnusa Tbk & $\mathrm{Rp} \quad 4.407 .513 .000 .000$ & 29,11 \\
\hline 6 & MITI & Mitra Investindo Tbk & $\mathrm{Rp} \quad 248.928 .487 .814$ & 26,24 \\
\hline 7 & SMMT & Golden Eagle Energy Tbk & $\mathrm{Rp} \quad 712.785 .113 .458$ & 27,29 \\
\hline 8 & RUIS & Radiant Utama Interinsco Tbk & Rp 1.091 .753 .891 .437 & 27,72 \\
\hline 9 & PTBA & $\begin{array}{l}\text { Tambang Batubara Bukit } \\
\text { Asam Tbk }\end{array}$ & Rp 16.894.043.000.000 & 30,46 \\
\hline \multirow[t]{3}{*}{10} & PKPK & Perdana Karya Perkasa Tbk & Rp $\quad 170.598 .564 .000$ & 25,86 \\
\hline & & Jumlah & Rp 58.266.737.659.217 & 281,13 \\
\hline & & Rata-Rata & Rp $\quad 5.826 .673 .765 .922$ & 28,11 \\
\hline
\end{tabular}

Sumber: Neraca Perusahaan (Data diolah)

Berdasarkan hasil penelitian, perusahaan pertambangan yang memiliki nilai ukuran perusahaan dilihat dari total asset tertinggi adalah PT Aneka Tambang Tbk (ANTM) sedangkan ukuran perusahaan dilihat dari total asset terendah adalah perusahaan Perdana Karya Perkasa Tbk (PKPK), dan ukuran perusahaan pada perusahaan pertambangan memiliki rata-rata sebesar Ln 28,11. Secara umum ukuran perusahaan pada perusahaan pertambangan yang terdaftar di BEI tahun 2015 tergolong pada perusahaan dengan skala besar. Dilihat dari total asset perusahaan, perusahaan yang dijadikan sampel memiliki asset lebih dari 100 Milyar rupiah. Hal tersebut sejalan dengan teori Menurut Prasetyantoko (Prasetyantoko 2008:257) menyatakan bahwa : "Assets total dapat menggambarkan ukuran perusahaan, semakin besar assets biasanya perusahaan tersebut semakin besar". Atau semakin besar penjualan maka keuntungan yang diperoleh perusahaan akan semakin banyak sehingga asset perusahaan semakin meningkat, dan perusahaan pun semakin besar. 
Audit delay adalah rentang waktu penyelesaian pelaksanaan audit laporan keuangan tahunan, diukur berdasarkan lamanya hari yang dibutuhkan untuk memperoleh laporan auditor independen atas audit laporan keuangan tahunan perusahaan, sejak tanggal tutup tahun buku perusahaan yaitu per 31 Desember sampai tanggal yang tertera pada laporan auditor independenUntuk mengetahui audit delay pada perusahaan pertambangan pada tahun 2015. Maka penulis sajikan hasil penelitian sebagai berikut :

Tabel 3

Audit delay

Perusahaan Pertambangan yang Terdaftar di BEI Tahun Buku 2015

\begin{tabular}{cclllc}
\hline No & Kode & \multicolumn{1}{c}{$\begin{array}{c}\text { Nama } \\
\text { Perusahaan }\end{array}$} & Tanggal Tutup Buku & $\begin{array}{c}\text { Tanggal Laporan } \\
\text { Audit }\end{array}$ & $\begin{array}{c}\text { Audit } \\
\text { delay }\end{array}$ \\
\hline 1 & ANTM & $\begin{array}{l}\text { Aneka Tambang } \\
\text { Tbk }\end{array}$ & 31 Desember 2015 & 29 Februari 2016 & 60 hari \\
\cline { 2 - 6 } 2 & CITA & $\begin{array}{l}\text { Cita Mineral } \\
\text { Investindo Tbk }\end{array}$ & 31 Desember 2015 & 15 Maret 2016 & 75 Hari \\
\cline { 2 - 6 } 3 & CKRA & $\begin{array}{l}\text { Cakra Mineral } \\
\text { Tbk }\end{array}$ & 31 Desember 2015 & 14 April 2016 & 105 Hari \\
\hline 4 & CTTH & Citatah Tbk & 31 Desember 2015 & 18 Maret 2016 & 78 Hari \\
\hline 5 & ELSA & Elnusa Tbk & 31 Desember 2015 & 11 Februari 2016 & 42 Hari \\
\cline { 2 - 6 } 6 & MITI & $\begin{array}{l}\text { Mitra Investindo } \\
\text { Tbk }\end{array}$ & 31 Desember 2015 & 28 Maret 2016 & 88 Hari \\
\cline { 2 - 6 } 7 & SMMT & $\begin{array}{l}\text { Golden Eagle } \\
\text { Energy Tbk }\end{array}$ & 31 Desember 2015 & 30 Maret 2016 & 90 Hari \\
\cline { 2 - 6 } 8 & RUIS & $\begin{array}{l}\text { Radiant Utama } \\
\text { Interinsco Tbk }\end{array}$ & 31 Desember 2015 & 21 Maret 2016 & 81 Hari \\
\cline { 2 - 6 } 9 & PTBA & Bukit Asam Tbk & 31 Desember 2015 & 29 Februari 2016 & 60 Hari \\
\cline { 2 - 6 } 10 & PKPK & $\begin{array}{l}\text { Perdana Karya } \\
\text { Perkasa Tbk }\end{array}$ & 31 Desember 2015 & 20 April 2016 & 111 Hari \\
\hline \multicolumn{5}{c}{ Rata-Rata Audit delay } \\
\hline
\end{tabular}

Sumber: Annual Report Perusahaan (Data diolah)

Berdasarkan hasil penelitian mengenai audit delay pada perusahaan pertambangan yang terdaftar di BEI Tahun 2015 menghasilkan bahwa dari 10 perusahaan yang diteliti sebanyak dua perusahaan yang mengalami audit delay melebihi ketentuan BAPEPAM-LK yaitu 90 hari atau bulan ketiga setelah penutupan tahun buku, dan dua diantaranya (Cakra Mineral Tbk (CKRA) dan Perdana Karya Perkasa Tbk (PKPK).

Dari uraian tersebut menunjukan bahwa perusahaan yang diteliti tidak semuanya mengalami audit delay, namun ada perusahaan yang tepat waktu dalam menyampaikan laporan keuangannya karena waktu audit yang diperoleh perusahaan kurang dari 90 hari.

Hal tersebut sejalan dengan teori menurut Theresia (Theresia 2005:6). Menyatakan bahwa Audit delay adalah rentang waktu penyelesaian pelaksanaan audit laporan keuangan tahunan, diukur berdasarkan lamanya hari yang dibutuhkan untuk memperoleh laporan auditor 
Sentralisasi Volume 8 (1) Hal : 43-56| 2019

Pengaruh Ukuran Perusahaan Terhadap Audit Delay... DOI: https://doi.org/10.33506/sl.v8i1.381

Dudi Badruzaman

independen atas audit laporan keuangan tahunan perusahaan, sejak tanggal tutup tahun buku perusahaan yaitu per 31 Desember sampai tanggal yang tertera pada laporan auditor independen.

\section{Pengaruh Ukuran Perusahaan terhadap Audit delay pada Perusahaan Pertambangan} yang Terdaftar di BEI Tahun 2015

Hasil Pengujian Hipotesis

\section{Tabel 4}

Nilai-Nilai untuk Perhitungan Regresi dan Korelasi

\begin{tabular}{ccccccc}
\hline No & Kode & $\begin{array}{c}\text { Ukuran } \\
\text { Perusahaan } \\
(\mathbf{X})\end{array}$ & $\begin{array}{c}\text { Audit } \\
\text { delay } \\
(\mathbf{Y})\end{array}$ & $\left.\mathbf{( X}^{\mathbf{2}}\right)$ & $\left(\mathbf{Y}^{\mathbf{2}}\right)$ & $(\mathrm{X.Y})$ \\
\hline 1 & ANTM & 31,04 & 60 & 963,73 & 3600 & 1862,6426 \\
\hline 2 & CITA & 28,66 & 75 & 821,35 & 5625 & 2149,4398 \\
\cline { 2 - 7 } 3 & CKRA & 27,61 & 105 & 762,51 & 11025 & 2899,4179 \\
\hline 4 & CTTH & 27,13 & 78 & 736,01 & 6084 & 2116,1085 \\
\hline 5 & ELSA & 29,11 & 42 & 847,64 & 1764 & 1222,8019 \\
\hline 6 & MITI & 26,24 & 88 & 688,56 & 7744 & 2309,1580 \\
\hline 7 & SMMT & 27,29 & 90 & 744,88 & 8100 & 2456,3201 \\
\hline 8 & RUIS & 27,72 & 81 & 768,33 & 6561 & 2245,2233 \\
\hline 9 & PTBA & 30,46 & 60 & 927,69 & 3600 & 1827,4789 \\
10 & PKPK & 25,86 & 111 & 668,87 & 12321 & 2870,7463 \\
\hline & Jumlah & $\mathbf{2 8 1 , 1 3}$ & $\mathbf{7 9 0 , 0 0}$ & $\mathbf{7 . 9 2 9 , 5 8}$ & $\mathbf{6 6 . 4 2 4 , 0 0}$ & $\mathbf{2 1 . 9 5 9 , 3 4}$ \\
\hline
\end{tabular}

\section{Analisis Regresi Linier Sederhana}

Analisis ini dimaksudkan untuk mengetahui adanya pengaruh Ukuran Perusahaan terhadap audit delay pada perusahaan pertambangan yang terdaftar di BEI tahun 2015. persamaan regresinya dengan menggunakan rumus $\mathrm{Y}=\mathrm{a}+\mathrm{bx}$, dimana $\mathrm{a}$ dan $\mathrm{b}$ dapat dicari dengan menggunakan rumus sebagai berikut :

$$
\begin{aligned}
& a=\frac{\left(\sum Y\right)\left(\sum X^{2}\right)-\left(\sum X\right)\left(\sum X Y\right)}{n\left(\sum X^{2}\right)-\left(\sum X\right)^{2}} \\
& a=\frac{(790)(7.929,58)-(281,13)(21.959,34)}{10(7.929,58)-(281,13)^{2}} \\
& a=\frac{6.264 .367-6.173 .493}{79.295,79-79.035,72} \\
& a=\frac{90.875}{260,07} \\
& a=349,422
\end{aligned}
$$

Sedangkan untuk mencari nilai b dapat menggunakan rumus : 


$$
\begin{aligned}
& \mathrm{b}=\frac{\mathrm{n}\left(\sum \mathrm{XY}\right)-\left(\sum \mathrm{X}\right)\left(\sum \mathrm{Y}\right)}{\mathrm{n}\left(\sum \mathrm{X}^{2}\right)-\left(\sum \mathrm{X}\right)^{2}} \\
& \mathrm{~b}=\frac{10(21.959,34)-(281,13)(790)}{10(7.929,58)-(281,13)^{2}} \\
& \mathrm{~b}=\frac{219.593,37-222.095}{79.295,79-79.035,72} \\
& \mathrm{~b}=\frac{-2.501,63}{260,07} \\
& \mathrm{~b}=-9,619
\end{aligned}
$$

Dudi Badruzaman

Jadi persamaan regresi sederhananya adalah :

$$
\mathrm{Y}=349,422-9,619 \mathrm{X}
$$

Berdasarkan hasil perhitungan regresi linier sederhana tersebut maka diperoleh nilai a sebesar 349,422 dan nilai b sebesar - 9,619. Artinya bahwa apabila nilai X (Ukuran Perusahaan) bertambah 1Milyar Rupiah maka nilai Y (Audit delay) akan menurun sebesar 9,619 hari, dan apabila X (Ukuran Perusahaan) nilainya adalah 0 atau menurun, maka Y (Audit delay) akan mengalami kenaikan 349,422 hari. Maka dapat disimpulkan bahwa terdapat hubungan antara ukuran perusahaan terhadap audit delay.

\section{Analisis Koefisien Korelasi}

Untuk mengetahui tingkat hubungan antara variabel pengaruh ukuran perusahaan terhadap audit delay pada perusahaan pertambangan yang terdaftar di BEI digunakan analisis korelasi product moment dengan menggunakan rumus sebagai berikut :

$$
\begin{aligned}
& r_{\mathrm{xy}}=\frac{\mathrm{n}\left(\sum \mathrm{XY}\right)-\left(\sum \mathrm{X}\right)\left(\sum \mathrm{Y}\right)}{\sqrt{\left\{\mathrm{n}\left(\mathrm{X}^{2}\right)-(\mathrm{X})^{2}\right\}\left\{\mathrm{n}\left(\sum \mathrm{Y}^{2}\right)-\left(\sum \mathrm{Y}\right)^{2}\right\}}} \\
& \mathrm{r}_{\mathrm{xy}}=\frac{10(21.959,34)-(281,13)(790)}{\sqrt{\left\{10(7.929,58)-(281,13)^{2}\right\}\left\{10(66.424)-(790)^{2}\right.}} \\
& r_{\mathrm{xy}}=\frac{219.593,4-222.095}{\sqrt{\{(79.295,79)-(79.035,72)\}\{(664.240)-(624.100)}} \\
& r_{\mathrm{xy}}=\frac{-2.502}{\sqrt{(260,07)(40.140)}} \\
& r_{\mathrm{xy}}=\frac{-2.502}{\sqrt{10.439 .265}} \\
& r_{\mathrm{xy}}=\frac{-2.502}{3.230,985} \\
& r_{\mathrm{xy}}=-0,774
\end{aligned}
$$

Dari perhitungan diatas maka dapat disimpulkan bahwa koefisien korelasi sebesar - 0,774 menunjukan bahwa keeratan hubungan antara ukuran perusahaan dengan Audit delay sebesar $77,4 \%$ korelasi bernilai negatif $(-)$. Hal ini menunjukan bahwa hubungan kedua 
variabel tidak searah, artinya peningkatan ukuran perusahaan akan diikuti penurunan audit delay, atau penurunan ukuran perusahaan akan diikuti peningkatan audit delay.

\section{Koefisien Determinasi}

Untuk mengetahui besarnya presentase pengaruh antara variabel terikat, serta untuk mengetahui pengaruh dari faktor lain diluar variabel bebas digunakan rumus sebagai berikut:

$$
\begin{aligned}
\mathrm{KD} & =(\mathrm{r})^{2} \times 100 \% \\
& =(-0,774)^{2} \times 100 \% \\
& =0,599 \times 100 \% \\
& =59,9 \%
\end{aligned}
$$

Berdasarkan perhitungan diatas, maka dapat ditarik kesimpulan bahwa ukuran perusahaan memiliki pengaruh terhadap audit delay pada perusahaan pertambangan yang terdaftar di BEI sebesar 59,9\% dan sisanya 40,1\% dipengaruhi faktor lain yang tidak diteliti.

\section{Uji Hipotesis (Uji Signifikansi atau Uji t)}

Uji t digunakan untuk menguji apakah suatu variabel bebas berpengaruh atau tidak terhadap variabel terikat. Untuk menentukan signifikansi maka digunakan rumus sebagai berikut :

$$
\begin{aligned}
t_{\text {hitung }} & =\frac{\mathrm{r} \sqrt{\mathrm{n}-2}}{\sqrt{1-\mathrm{r}^{2}}} \\
& =-0,774 \frac{\sqrt{10-2}}{\sqrt{1-(-0,774)^{2}}} \\
& =-0,774 \frac{\sqrt{8}}{\sqrt{1-0,599}} \\
& =-0,774 \frac{2,83}{\sqrt{0,401}} \\
& =-0,774 \frac{2,83}{0,633} \\
& =-0,774 \times 4,470 \\
& =-3,460
\end{aligned}
$$

Berdasarkan perhitungan diperoleh $\mathrm{t}_{\text {hitung }}$ sebesar $-3,460$. Kemudian dibandingkan dengan $\mathrm{t}_{\text {tabel}}$, dengan menggunakan tingkat signifikansi 0,05 dan derajat kebebasan $(\mathrm{dk})=10-$

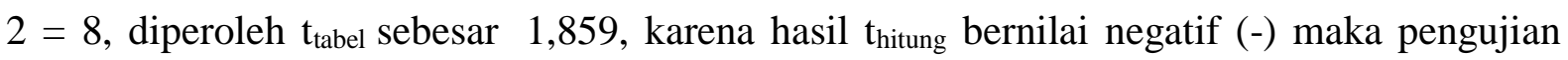
dilakukan disebelah kiri. Maka didapatkan perbandingan $-t_{\text {hitung }}<t_{\text {tabel }}(-3,460<1,859)$ hipotesis ditolak dan dengan taraf signifikansi $0,002<0,05$ artinya ukuran perusahaan berpengaruh signifikan terhadap audit delay. Jadi dari perhitungan tersebut menghasilkan 
bahwa ukuran perusahaan berpengaruh negatif dan signifikan terhadap audit delay pada perusahaan pertambangan yang terdaftar di BEI Tahun 2015.

Dengan demikian hipotesis yang menyatakan ukuran perusahaan berpengaruh positif terhadap audit delay pada perusahaan pertambangan yang terdaftar di BEI Tahun 2015 ditolak. Hasil perhitungan diatas menghasilkan bahwa ukuran perusahaan berpengaruh negatif dan signifikan terhadap audit delay pada perusahaan pertambangan yang terdaftar di BEI tahun 2015. Hasil penelitian ini tidak mendukung hasil yang telah dilakukan oleh peneliti sebelumnya yaitu Azhari (Azhar,2014:15) dan Khalatbari et al. (Khalatbari et al 2013:56) pada perusahaan perbankan yang terdaftar di BEI yang menemukan adanya pengaruh yang positif antara ukuran perusahaan dan audit delay. Khalatbari menyatakan bahwa: "Audit delay akan semakin lama apabila ukuran perusahaan yang diaudit semakin besar". Hal ini berkaitan dengan semakin banyaknya jumlah sampel yang harus diambil dan semakin luas prosedur audit yang harus ditempuh.

Dan hasil penelitian ini tidak mendukung teori yang ada yaitu Menurut Boynton dan Kell (1996) dalam Utami (Boynton,Kell,2006:23) menyatakan bahwa : Ukuran perusahaan berpengaruh terhadap Audit delay, semakin besar perusahaan maka audit delay semakin lama, hal ini berkaitan dengan semakin banyaknya jumlah sampel yang harus diambil dan semakin luasnya prosedur audit yang dilakukan sehingga waktu auditor untuk menyelesaikan proses auditnya semakin lama.

Sedangkan hasil penelitian ini mendukung hasil penelitian yang dilakukan oleh Setyorini (2008) yaitu ukuran perusahaan yang dinilai dari seberapa besar nilai harta yang dimiliki perusahaan berpengaruh negatif terhadap audit delay. Adanya pengaruh negatif antara ukuran perusahaan dengan audit delay menunjukkan bahwa manajemen perusahaan besar, mempunyai dorongan untuk mengurangi penundaan laporan keuangan. Menurut Rachamawati (2008) menyatakan bahwa ukuran perusahaan berpengaruh signifikan terhadap audit delay. Hal ini disebabkan oleh semakin baiknya sistem pengendalian internal perusahaan besar sehingga dapat mengurangi tingkat kesalahan dalam penyusunan laporan keuangan yang memudahkan auditor dalam melakukan audit laporan keuangan.

Hasil penelitian ini menunjukan bahwa ukuran perusahaan berpengaruh negatif dan signifikan tehadap audit delay, yang berati bahwa semakin besar ukuran perusahaan yang dilihat dari total asset perusahaan maka akan semakin cepat audit delay yang dialami perusahaan dan sebaliknya semakin kecil ukuran perusahaan yang dilihat dari total asset maka audit delay yang dialami perusahaan akan semakin lama. Hal ini karena perusahaan yang sudah 
go publik atau perusahaan besar pasti memiliki pengendalian internal yang baik. Dari pembahasan diatas, maka dapat disimpulkan bahwa ukuran perusahaan berpengaruh negatif dan signifikan terhadap audit delay pada perusahaan pertambangan yang terdaftar di BEI Tahun 2015. Artinya bahwa semakin besar ukuran perusahaan maka audit delay akan semakin cepat, sehingga perusahaan akan tepat waktu dalam penyampaian laporan keuangannya. Dan sebaliknya semakin kecil ukuran perusahaan maka audit delay akan semakin lama, sehingga perusahaan akan mengalami keterlambatan dalam penyampaian laporan keuangannya pada publik .

\section{Simpulan}

Dari pembahasan yang telah dilakukan berdasarkan data-data yang diperoleh dari perusahaan pertambangan yang terdaftar di BEI tahun 2015, maka dapat dibuat kesimpulan sebagai berikut ; 1) Ukuran Perusahaan dilihat dari total asset tertinggi yaitu perusahaan Aneka Tambang Rp.30.356.850.890.000, sedangkan ukuran perusahaan dengan asset terendah yaitu perusahaan Perdana Karya Perkasa Tbk (PKPK) dengan asset sebesar Rp. 170.598.564.000. Jadi secara umum ukuran perusahaan pertambangan termasuk pada perusahaan dengan skala besar, karena berdasar dari total asset perusahaan Tahun 2015 yaitu memiliki asset lebih dari Rp.100 Milyar (keputusan BAPEPAM No 11/PM/1997). 2) Perusahaan dengan waktu pelaksanaan audit paling cepat dialami oleh perusahaan Elnusa Tbk (ELSA) dengan waktu pelaksanaan audit selama 42 hari, sedangkan perusahaan dengan waktu pelaksanaan audit terlama dialami oleh Perdana Karya Perkasa Tbk (PKPK) dengan waktu pelaksanaan audit selama 111 hari. Audit Delay perusahaan pertambangan bila ditinjau dari batas penerbitan Laporan Keuangan dengan penerbitan opini/ Laporan Audit memiliki rata-rata 79 hari. Berdasarkan peraturan BAPEPAM No 36/PM/2003 termasuk menyampaikan secara tepat waktu dalam kurun waktu kurang dari 90 hari. 3) Ukuran Perusahaan berpengaruh negatif dan signifikan terhadap audit delay pada perusahaan pertambangan yang terdaftar di BEI Tahun 2015. Artinya bahwa semakin besar ukuran perusahaan maka audit delay akan semakin cepat, sehingga perusahaan akan tepat waktu dalam penyampaian laporan keuangannya. Dan sebaliknya semakin kecil ukuran perusahaan maka audit delay akan semakin lama, sehingga perusahaan akan mengalami keterlambatan dalam penyampaian laporan keuangannya pada publik . 


\section{Daftar Pustaka}

Dudi Badruzaman

Agoes, Sukrisno dan Hoesada. 2012. Bunga Rampai Auditing. Edisi kedua. Jakarta: Salemba Empat.

Bayangkara, IBK. 2008. Audit Manajemen Prosedur dan Implementasi. Jakarta: Salemba Empat

Boynton C. William. Et. Al. 2007. Modern Auditing. Jilid satu. Edisi tujuh. Diterjemahkan oleh Paul A Radjoe, Gina Gania, Jakarta : Penerbit Erlangga.

Harahap, Sofyan Syafri. 2009. Analisis Kritis Atas Laporan Keuangan.. Jakarta: Raja Grafindo Persada

Ikatan Akuntan Indonesia. 2009. Pernyataan Standar AkuntansiKeuangan(PSAK) No. 1 Penyajian Laporan Keuangan (Revisi 2009). Jakarta: Salemba Empat.

Jurica, Sabrina. 2011. Pengujian Faktor-faktor yang Mempengaruhi Audit Delay. Jurnal Nasional Universitas Bakrie.

Jusuf, Al Haryono. 2011. Dasar-dasar Akuntansi, jilid 2 Cetakan Pertama Sekolah Yogyakarta:Tinggi Ekonomi Yayasan Keluarga Pahlawan Negara

Kasmir. 2008. Bank dan Lembaga Keuangan Lainnya. Edisi Revisi 2008. Jakarta : PT. Rajagrafindo Persada.

Muawanah, Umi dan Fahmi Poernawati. 2008. Konsep Dasar Akuntansi dan Pelaporan Keuangan jilid 1. Jakarta : Direktorat Pembinaan Sekolah Menengah Kejuruan.

Mulyadi. 2002. Auditing. Edisi keenam. Cetakan pertama. Jakarta: Salemba Empat

Panjaitan, Bastian. 2010. Analisis Pengaruh Total Aktiva, Jenis Opini Auditor, Ukuran KAP dan Rasio Profitabilitas Terhadap Audit Delay pada Bank-Bank yang Terdaftar di BEI. Tesis. Universitas Indonesia. Jakarta

Prasetyantoko, A., 2008. Bencana Finansial Stabilitas sebagai Barang Publik. Kompas Media Nusantara. Jakarta

Purnamasari, Carmelia Putri. 2012. Analisis Faktor-Faktor Yang Mempengaruhi Audit Delay Pada Perusahaan LQ 45 Yang Terdaftar Di Bursa Efek Indonesia. Skripsi. Universitas Gunadarma.

Rahayu,Siti Kurnia dan Suhayati,eli. 2010. AUDITING, Konsep Dasar dan Pedoman Pemriksaan Akuntan Publik. Yogyakarta : Graha Ilmu.

Reeve, James M. Dan Carl S. Warren. et.al. 2009. Pengantar Akuntansi Adaptasi Indonesia Buku 1. Jakarta: Salemba Empat.

Ristin,Fika. 2015. Faktor-faktor yang Mempengaruhi Audit Delay pada Perusahanan Manufaktur yang Terdaftar di BEI. Skripsi.Universitas Hasanudin. 
Sentralisasi Volume 8 (1) Hal : 43-56 | 2019

Pengaruh Ukuran Perusahaan Terhadap Audit Delay... DOl: https://doi.org/10.33506/sl.v8i1.381

Dudi Badruzaman 